\title{
Gambaran kebersihan gigi dan mulut pada siswa berkebutuhan khusus di SLB YPAC Manado
}

\author{
${ }^{1}$ Christavia J. Motto \\ ${ }^{2}$ Christy N. Mintjelungan \\ ${ }^{3}$ Shane H. R. Ticoalu
}

\author{
${ }^{1}$ Kandidat Skripsi Program Studi Pendidikan Dokter Gigi Fakultas Kedokteran \\ ${ }^{2}$ Program Studi Pendidikan Dokter Gigi Fakultas Kedokteran \\ ${ }^{3}$ Bagian Anatomi-Histologi Fakultas Kedokteran \\ Universitas Sam Ratulangi Manado \\ Email: christavianelwan@yahoo.co.id
}

\begin{abstract}
Oral health is an important part of the overall body health. Children with special needs are at risk or have chronic physical, developmental, behavioral, or emotional condition, therefore, they commonly require some assistance in maintaining their cleanliness, especially the oral hygiene. The indicator degree of oral hygiene in Indonesia is the status of oral hygiene degree with an average of Simplified Oral Hygiene Index (OHI-S) $<1.2$ obtained from summing the number debris index and calculus index. This study was aimed to describe the dental and oral hygiene in students with special needs at SLB YPAC Manado. This was a descriptive study with a cross sectional design. Subjects were 36 students, aged 10-28 years, cooperative, and had letters of consent signed by their parents or proxy parents, obtained by using total sampling method. Data were analyzed manually and presented in tables, figures, and percentages, grouped based on their characteristics. The results showed that the students with special needs in SLB YPAC Manado had an average score of OHI-S of 1.3 with a total scores of Simplified Debris Index (DI-S) 0.9 and Simplified Calculus Index (CI-S) 0.4 which belonged to the moderate category.
\end{abstract}

Keywords: oral hygiene, students with special needs

\begin{abstract}
Abstrak: Kesehatan gigi dan mulut menjadi salah satu bagian penting dari kesehatan tubuh secara keseluruhan. Anak berkebutuhan khusus (ABK) berisiko tinggi atau mempunyai kondisi kronis secara fisik, perkembangan, perilaku atau emosi sehingga memerlukan bantuan dalam menjaga kebersihan diri sendiri khususnya kebersihan gigi dan mulut. Indikator derajat kebersihan gigi dan mulut di Indonesia ialah status derajat kebersihan gigi dan mulut dengan rerata Oral Hygiene Index Simplified (OHI-S) <1,2 yang didapatkan dari menjumlahkan angka debris indeks dan kalkulus indeks. Penelitian ini bertujuan untuk mengetahui gambaran kebersihan gigi dan mulut pada siswa berkebutuhan khusus di SLB YPAC Manado. Jenis penelitian ialah deskriptif dengan desain potong lintang. Subyek penelitian sebanyak 36 siswa berusia 10-28 tahun, kooperatif, serta bersedia menjadi responden berdasarkan surat persetujuan yang ditandatangani oleh orang tua atau wali, diperoleh dengan metode total sampling. Data diolah secara manual dan ditampilkan dalam bentuk tabel, gambar, dan persentase yang dikelompokkan berdasarkan karakteristiknya. Hasil penelitian menunjukkan dari 36 siswa berkebutuhan khusus di SLB YPAC Manado didapatkan rerata skor OHI-S 1,3 dengan jumlah skor Debris Index Simplified (DI-S) 0,9 dan skor Calculus Index Simplified (CI-S) 0,4 yang tergolong pada status kebersihan gigi dan mulut sedang.

Kata kunci: kebersihan gigi dan mulut, siswa berkebutuhan khusus
\end{abstract}


Kesehatan gigi dan mulut merupakan salah satu bagian yang tidak dapat dipisahkan dari kesehatan tubuh secara keseluruhan. Perawatan gigi dan mulut secara keseluruhan diawali dari kebersihan gigi dan mulut pada setiap individu. Prevalensi nasional penyakit gigi dan mulut di Indonesia sebesar $23,4 \%{ }^{1}$

Salah satu indikator kesehatan gigi dan mulut yaitu tingkat kebersihan gigi dan mulut. Hal tersebut dapat dilihat secara klinis dari ada tidaknya deposit-deposit organik, seperti pelikel, materi alba, debris, kalkulus, dan plak gigi. Plak merupakan deposit lunak yang membentuk lapisan biofilm dan melekat pada permukaan gigi dan gusi serta permukaan jaringan keras lainnya dalam rongga mulut. ${ }^{2}$ Risiko yang ditimbulkan akibat kondisi kebersihan gigi dan mulut yang buruk dapat meningkatkan terjadinya karies dan penyakit periodontal. ${ }^{3}$

Faktor lingkungan, distribusi penduduk dan perilaku siswa terhadap kebersihan gigi dan mulut merupakan faktor yang memengaruhi dalam peningkatan upaya kesehatan gigi dan mulut. ${ }^{2}$ Indikator derajat kebersihan gigi dan mulut di Indonesia memiliki status derajat kebersihan gigi dan mulut dengan rerata Oral Hygiene Index Simplified (OHI_S) $<1,2 .{ }^{4} \quad$ Indikator kebersihan gigi dan mulut (OHI-S) didapatkan dari menjumlahkan angka debris indeks dan kalkulus indeks. Indeks OHI-S adalah keadaan kebersihan gigi dan mulut dari responden yang dinilai dari adanya sisa makanan (debris) dan kalkulus (karang gigi) pada permukaan gigi. ${ }^{5}$

Anak berkebutuhan khusus (ABK) adalah anak yang berisiko tinggi atau mempunyai kondisi kronis secara fisik, perkembangan, perilaku, atau emosi. ${ }^{6}$ Anak berkebutuhan khusus merupakan istilah lain untuk menggantikan kata anak luar biasa (ALB) yang menandakan adanya kelainan khusus dan mempunyai karakteristik yang berbeda antara satu dan lainnya. Di Indonesia, ABK yang mempunyai gangguan perkembangan antara lain: tunanetra (kehilangan indera penglihatan), tunarungu (keterbatasan pada pendengaran dan berbicara), tunagrahita (retardasi mental), tunadaksa (keterbatasan pada kondisi fisik atau motorik), tunalaras (karakteristik anak yang sering membuat keonaran secara berlebihan), autisme (anak dengan kelainan pada ketidakmampuan berbahasa), hiperaktif (suatu gejala yang diakibatkan oleh faktor kerusakan pada otak, kelainan emosional dan kurang dengar), anak dengan gangguan pada waktu belajar (siswa yang sering kali mempunyai prestasi rendah dalam bidang akademik tertentu seperti membaca, menulis, dan berhitung), serta anak dengan kelainan perkembangan ganda (tunaganda). ${ }^{7,8}$

Individu berkebutuhan khusus memiliki tingkat kesehatan dan kebersihan gigi dan mulut yang lebih rendah dibandingkan dengan individu normal. Tingkat pengetahuan tentang menjaga kesehatan gigi dan mulut yang rendah menyebabkan tingginya angka karies, kalkulus, dan debris. $^{9}$

Saat ini, penelitian tentang status kebersihan gigi dan mulut pada ABK belum banyak dilakukan dikarenakan berbagai alasan misalnya, anak tersebut tidak kooperatif. Penelitian ini bertujuan untuk mendapatkan status kebersihan gigi dan mulut pada siswa berkebutuhan khusus di SLB YPAC Manado agar dapat mengetahui pola hidup para siswa serta perhatian orang tua dan pendidik dalam membantu menjaga kesehatan gigi dan mulut anak-anak tersebut.

\section{BAHAN DAN METODE PENELITIAN}

Jenis penelitian ini ialah deskriptif dengan desain potong lintang. Penelitian ini dilaksanakan di SLB YPAC Manado pada bulan Desember 2016. Populasi yaitu siswa berkebutuhan khusus, berusia 10-28 tahun di SLB YPAC Manado berjumlah 36 orang yang telah memenuhi kriteria inklusi. Subyek penelitian diperoleh dengan metode total sampling. Instrumen penelitian yaitu diagnostic set (kaca mulut, sonde, pinset dental), disclosing solution dan formulir pemeriksaan OHI-S. Pengolahan data dilakukan secara manual dan dikelompokkan berdasarkan karakteristiknya dalam bentuk tabel, gambar dan persentase. 


\section{HASIL PENELITIAN}

Subjek penelitian berjumlah 36 anak dan dibedakan berdasarkan karakteristik jenis kelamin. Jumlah subjek dengan jenis kelamin perempuan lebih banyak dibandingkan dengan jenis kelamin lakilaki (Tabel 1). Yang terbanyak didapatkan ialah siswa berusia 10-12 tahun (19 siswa) dan yang paling sedikit berusia $>21$ tahun (2 siswa (Tabel 2)). Tabel 3 menunjukkan karakteristik subjek penelitian berdasarkan jumlah siswa berkebutuhan khusus di SLB YPAC Manado. Yang terbanyak ialah subyek tunagrahita $(44,5 \%)$.

Tabel 1. Karakteristik subjek penelitian berdasarkan jenis kelamin

\begin{tabular}{ccc}
\hline Jenis kelamin & Jumlah & \% \\
\hline Laki-laki & 9 & 25 \\
Perempuan & 27 & 75 \\
Total & 36 & 100 \\
\hline
\end{tabular}

Tabel 2. Karakteristik subjek penelitian berdasarkan usia

\begin{tabular}{ccc}
\hline Usia (tahun) & $\mathbf{n}$ & $\mathbf{\%}$ \\
\hline $10-12$ & 19 & 52,77 \\
$13-15$ & 8 & 22,22 \\
$16-18$ & 4 & 11,11 \\
$19-21$ & 3 & 8,33 \\
$>21$ & 2 & 5,6 \\
Total & 36 & 100 \\
\hline
\end{tabular}

Tabel 3. Karakteristik subjek penelitian berdasarkan jenis kebutuhan khusus

\begin{tabular}{ccc}
\hline $\begin{array}{c}\text { Jenis kebutuhan } \\
\text { khusus }\end{array}$ & $\mathbf{n}$ & $\mathbf{\%}$ \\
\hline Tunarungu & 12 & 33,33 \\
Tunadaksa & 8 & 22,22 \\
Tunagrahita & 16 & 44,5 \\
Total & 36 & 100 \\
\hline
\end{tabular}

Tabel 4 menunjukkan distribusi status kebersihan gigi dan mulut berdasarkan kebutuhan khusus yang ada di SLB YPAC Manado.

Tabel 4. Karakteristik subjek penelitian berdasarkan kebutuhan khusus

\begin{tabular}{lcccccccc}
\hline \multirow{2}{*}{$\begin{array}{c}\text { Jenis } \\
\text { kebutuhan khusus }\end{array}$} & \multicolumn{9}{c}{ OHI-S } \\
\cline { 2 - 10 } & \multicolumn{2}{c}{ Baik } & \multicolumn{2}{c}{ Sedang } & \multicolumn{2}{c}{ Buruk } & \multicolumn{2}{c}{ Total } \\
\cline { 2 - 10 } & $\mathrm{n}$ & $\%$ & $\mathrm{n}$ & $\%$ & $\mathrm{n}$ & $\%$ & $\mathrm{n}$ & $\%$ \\
\hline Tunarungu & 7 & 58,3 & 5 & 41,7 & 0 & 0 & 12 & 100 \\
Tunadaksa & 3 & 37,5 & 5 & 62,5 & 0 & 0 & 8 & 100 \\
Tunagrahita & 3 & 18,7 & 13 & 81,3 & 0 & 0 & 16 & 100 \\
Total & & & & & & & 36 & 100 \\
\hline
\end{tabular}

Distribusi status kebersihan gigi dan mulut dapat dibedakan berdasarkan kriteria baik, sedang dan buruk berdasarkan OHI-S (Tabel 5). Sebagian besar subjek penelitian dengan jumlah 23 orang $(63,89 \%)$ memiliki OHI-S sedang dengan skor 1,7; tidak terdapat subyek dengan kategori buruk.

Rerata status kebersihan gigi dan mulut seluruh subjek penelitian dihitung berdasarkan skor OHI-S dengan menjumlahkan skor DI-S dan CI-S. Dari total 36 subjek penelitian didapatkan rerata skor OHI-S 1,3 dengan jumlah skor DI-S=0,9 dan skor CI$\mathrm{S}=0,4$, yang tergolong pada status kebersihan gigi dan mulut sedang.
Tabel 5. Distribusi status kebersihan gigi dan mulut ABK di SLB YPAC Manado

\begin{tabular}{cccc}
\hline OHI-S & n & $\%$ & $\begin{array}{c}\text { Skor } \\
\text { OHI-S }\end{array}$ \\
\hline Baik & 13 & 36,11 & 0,9 \\
Sedang & 23 & 63,89 & 1,7 \\
Buruk & 0 & 0 & 0 \\
Total & 36 & 100 & 1,3 \\
\hline
\end{tabular}

\section{BAHASAN}

Berdasarkan hasil penelitian (Tabel 5) dari 36 subjek penelitian didapatkan 13 subyek $(36,11 \%)$ dengan tingkat kebersihan gigi dan mulut baik, 23 subyek $(63,89 \%)$ dengan kriteria sedang; tidak terdapat subyek yang tergolong kriteria buruk. 
Secara keseluruhan rerata kebersihan mulut tergolong pada kriteria sedang dengan hasil perhitungan OHI-S 1,3. Penelitian serupa oleh Mawardiyanti ${ }^{10}$ di SLB Bintoro Jember mendapatkan 15 responden; tidak terdapat responden dengan kriteria buruk. Hasil penelitian ini menunjukkan bahwa siswa di SLB YPAC termasuk kategori baik dalam menjaga kebersihan gigi dan mulut.

Kebersihan gigi dan mulut dipengaruhi oleh perilaku pemeliharaan kebersihan gigi dan mulut pada masing-masing individu. Menurut Widi, ${ }^{11}$ salah satu faktor yang memengaruhi tingkat kebersihan gigi dan mulut yaitu perilaku. Perilaku dapat dibentuk dari lingkungan dan juga faktor genetik. Pembentukan perilaku yang berasal dari lingkungan dapat berupa pengalaman yang diperoleh dari lingkungan kehidupan sehari-hari, sedangkan untuk faktor genetik berupa perilaku yang diturunkan dari orang tua. ${ }^{11}$

Terdapat beberapa perilaku yang memengaruhi subjek penelitian seperti waktu dan cara menyikat gigi yang benar. Menyikat gigi merupakan cara yang umum dianjurkan untuk membersihkan berbagai kotoran yang melekat pada permukaan gigi dan gusi. Menyikat gigi yang benar yaitu minimal dua kali sehari setiap pagi hari setelah sarapan dan malam hari sebelum tidur. Hal ini bertujuan untuk membersihkan sisa makanan yang tertinggal pada gigi dan gusi. Perilaku menggosok gigi dapat mengurangi terjadinya penyakit gigi seperti karies dan jaringan periodontal. ${ }^{12}$

Hasil penelitian Widasari ${ }^{13}$ di Desa Bintoro Patrang, Balung dan Kaliwates pada tahun 2014 menunjukkan bahwa anak tunarungu memiliki kondisi OHI-S yang lebih rendah daripada anak yang tidak tunarungu. Hal ini disebabkan karena informasi yang didapatkan oleh anak tunarungu, terutama tentang kesehatan gigi dan mulut tidak ditangkap secara maksimal sehingga membentuk sebuah perilaku yang keliru yang dapat memengaruhi kebersihan gigi dan mulut. Dalam hal ini, kelompok anak tunarungu dapat dikategorikan sebagai kelompok anak dengan risiko tinggi karena rentan terjadi karies dan penyakit periodontal dibandingkan dengan anak yang tidak tuna rungu. ${ }^{13}$

Suatu pengetahuan dipengaruhi oleh tingkat pendidikan, banyaknya informasi yang diperoleh, keadaan lingkungan, pengalaman, usia, dan status ekonomi seseorang. Hal ini dipengaruhi oleh pengetahuan tentang sikap dan tindakan seseorang untuk mengaplikasikan informasi yang didapatkan untuk diwujudkan dalam kehidupan sehari-hari dan menjadi kebiasaan. Anak tunarungu lebih mudah menyerap informasi sebagai pengetahuan dengan cara peragaan atau praktik sehingga lebih mudah memahami informasi apapun yang disampaikan dan dapat diwujudkan dalam bentuk perilaku yang sesuai dengan teori perilaku yang dikenal dengan konsep K-A-P (Knowledge-Attitude-Practice). ${ }^{14}$

Perbandingan penelitian yang dilakukan pada anak retardasi mental (tunagrahita) oleh Azzahra et al. ${ }^{15}$ menunjukkan bahwa indeks kebersihan rongga mulut pada anak retardasi mental berdasarkan jenis kelamin diduga berkaitan dengan faktor hormonal. Anak perempuan lebih cepat mengalami pendewasaan dan sering mengalami gangguan keseimbangan hormonal sehingga mudah mengalami gangguan emosional, stress, dan sering mengonsumsi makanan dan minuman yang mengandung gula di antara jam makan. Makanan dan minuman mengandung gula yang lengket akan mempermudah perlekatan debris atau sisa makanan. ${ }^{15}$

Indeks kebersihan rongga mulut pada anak retardasi mental berdasarkan tingkat usia diduga berhubungan dengan teori kognitif menurut Piaget yang menyatakan perkembangan kognitif anak terjadi dalam empat tahapan. Masing-masing tahapan berhubungan dengan usia dan tersusun dari jalan pikiran yang berbeda-beda. Tahapan Piaget itu merupakan fase sensorimotor, pra-operasional, operasional konkret, dan operasional formal. Kelompok anak usia 811 tahun termasuk dalam tahapan operasional konkret yaitu anak sudah mulai bisa menalar secara logis tentang kejadiankejadian nyata dan mampu mengklasi- 
fikasikan suatu objek ke dalam kelompok yang berbeda-beda. Kemampuan untuk menggolong-golongkan sudah ada, tetapi si anak belum bisa memecahkan masalah secara abstrak. Kelompok anak usia 12-15 tahun termasuk dalam tahapan operasional formal, yaitu anak remaja berpikir secara lebih abstrak, idealis, dan logis. Jadi dari segi kognitif, anak usia 8-15 tahun sebenarnya sudah mampu memahami dan bernalar tentang kebersihan rongga mulut, misalnya seperti menggolongkan menyikat gigi dua kali dalam sehari tetapi masih tidak bisa memecahkannya atau melakukannya secara ideal. Pedoman level kebersihan rongga mulut dengan faktor usia yang biasa digunakan pada anak normal tidak dapat disamakan dengan anak retardasi mental. Pada anak normal usia mentalnya sama atau lebih tinggi dari usia kronologisnya. Anak retardasi mental, usia mentalnya akan lebih rendah dari usia kronologisnya dan keadaan ini akan memengaruhi perkembangan kemampuan kognitif dan psikomotorik terutama dalam hal menjaga kebersihan rongga mulut. ${ }^{16,17}$

Berdasarkan teori Blum, status kebersihan rongga mulut seseorang atau masyarakat dipengaruhi oleh empat faktor penting, yaitu: keturunan, lingkungan (fisik maupun sosial budaya), perilaku, dan pelayanan kesehatan. Dari keempat faktor tersebut, perilaku memegang peranan yang penting dalam mempengaruhi status kebersihan rongga mulut secara langsung. Berkaitan dengan teori di atas, maka frekuensi menyikat gigi sebagai bentuk perilaku akan memengaruhi baik atau buruknya kebersihan rongga mulut. ${ }^{3,11}$

Cara terbaik untuk mengeliminasi debris dan dental plak ialah menyikat gigi dengan sikat gigi manual ataupun sikat gigi elektrik. Frekuensi menyikat gigi yang kurang akan menyebabkan tingginya kemungkinan oral hygiene yang buruk. Jenis sikat gigi yang digunakan yaitu sikat gigi yang umumnya dapat diperoleh di supermarket atau toko yang menjual kebutuhan sehari-hari dengan bulu sikat yang halus dan sesuai dengan kategori usia pemakainya. $^{9,18}$
Penelitian yang dilakukan sebelumnya di lokasi yang sama (SLB YPAC Manado) pada tahun 2011 oleh Putra et al. ${ }^{19}$ dengan mengambil sampel penelitian berdasarkan 3 jenis ketunaan memperoleh hasil persentase kebersihan gigi dan mulut yaitu baik 9 anak (29,03\%), sedang 18 anak $(58,07 \%)$ dan buruk 4 anak (12,90\%). Dengan mengambil jenis ketunaan pada anak tunadaksa 4 orang, tunagrahita 17 orang, dan tunarungu 10 orang diperoleh skor 1,7 dengan kategori sedang. Dengan melihat hasil penelitian di atas dapat disimpulkan bahwa tingkat kebersihan gigi dan mulut pada ABK di SLB YPAC Manado mengalami peningkatan. Hal ini tentunya tidak lepas dari peran serta orang tua dan guru yang turut membantu siswa dalam aktifitas menjaga kebersihan diri sendiri baik di rumah maupun di lingkungan sekolah. Namun, peningkatan status kebersihan gigi dan mulut masih terus dilakukan agar ke depan hasilnya akan lebih baik lagi. ${ }^{19,20}$

\section{SIMPULAN}

Dari hasil penelitian terhadap siswa berkebutuhan khusus di SLB YPAC Manado dapat disimpulkan bahwa rerata status kebersihan gigi dan mulut berdasarkan Oral Hygiene Index Simplified (OHI-S) tergolong dalam kategori sedang dengan skor 1,3 .

\section{SARAN}

1. Dapat dilakukan penelitian status kebersihan gigi dan mulut pada siswa berkebutuhan khusus di SLB lainnya untuk menambah usaha promotif dan preventif tentang kesehatan gigi dan mulut.

2. Diperlukan perhatian orang tua, tenaga pendidik dan dokter gigi dalam upaya menjaga kesehatan gigi dan mulut pada siswa berkebutuhan khusus dengan cara melakukan pemeriksaan rutin setiap 6 bulan sekali.

3. Memberikan pendidikan dan penyuluhan tentang pentingnya menjaga kebersihan gigi dan mulut pada siswa yang berkebutuhan khusus. 
DAFTAR PUSTAKA

1. Dahlan S. Statistik untuk Kedokteran dan Kesehatan (3rd ed). Jakarta: Salemba Medika, 2013; p. 69-74.

2. Saryono. Metodologi Penelitian Kesehatan (4th ed). Yogyakarta: Mitra Cendika, 2011; p. 73-4.

3. Anitasari S, Rahayu N. Hubungan frekuensi menyikat gigi dengan tingkat kebersihan gigi dan mulut siswa sekolah dasar negeri di Kecamatan Palaran Kotamadya Samarinda Provinsi Kalimantan Timur. Dent J. 2008;38(2):88.

4. Kaur M, Jogindra V, Kaur S. Self care deficits of admitted. patients. Nursing and Midwifery Research Journal. 2008;2(1):10-5

5. Nurhidayat O, Eram TP, Wahyono B. Perbandingan media power point dengan flip chart dalam meningkatkan pengetahuan kesehatan gigi dan mulut. Unnes J Pub Health. 2012;1(1):32-5.

6. Chamidah AN. Pendidikan inklusif untuk anak dengan kebutuhan khusus. Jurnal Pendidikan Khusus. 2010;7(2):1-5.

7. Kosasih E. Cara Bijak Memahami Anak Berkebutuhan Khusus. Bandung: Yrama Widya, 2012; p. 1.

8. Delphi B. Pembelajaran Anak Tunagrahita. Bandung: Refika Aditama, 2006; p. 2.

9. Jain M, Marthur A, Sawla L, Choudhary G, Kabra K, Duraiswamy P. Oral health status of mentally disabled subjects in India. $\mathbf{J}$ Oral Sci. 2009;51(3):333-40.

10. Mawardiyanti NS. Status kebersihan gigi dan mulut serta karies pada anak berkebutuhan khusus di SLB Bintoro Jember [Skripsi]. Jember: Universitas Jember; 2012.

11. Widi ER. Hubungan perilaku membersihkan gigi terhadap tingkat kebersihan mulut siswa sekolah dasar negeri wilayah kerja Puskesmas
Gladak Pakem Kabupaten Jember. JKGI. 2006;10(3):10.

12. Purnomo I, Lestari S. Studi tentang faktorfaktor yang berhubungan dengan status kesehatan gigi dan mulut siswa SMK Yependa Wiradesa Kabupaten Pekalongan. 2013. Available from URL:http://www.journal.unikal.ac.id/i ndex.php/lppm/article/download/263/1 99

13. Widasari D. Perbedaan status kesehatan pada anak tunarungu dengan tidak tunarungu usia 6-12 tahun. UNEJ. Digital Repository. 2014;11.

14. Notoatmodjo S. Kesehatan Masyarakat: Ilmu dan Seni. Jakarta: Rineka Cipta, 2007; p. 7.

15. Azzahra NN, Wasilah S, Aspriyanto D. Indeks kebersihan rongga mulut pada anak retardasi mental. Jurnal Kedokteran Gigi. 2014;II(1):80.

16. Dewi SRP. Keadaan oral hygiene pada anak cacat mental berdasarkan tingkat IQ [Skripsi]. Medan: Fakultas Kedokteran Gigi Universitas Sumatera Utara; 2003

17. Santrock JW. Psikologi Pendidikan (2nd ed). Jakarta: Kencana, 2007; p. 46-56.

18. Rodelo JJV, Solis CEM, Maupome G, Sanchez AAV, Rojo LL, Viedas MVPL. Socioeconomic and sociodemographic variables associated with oral hygiene status in Mexican school children aged 6 to 12 years. J Periodontal. 2007; 78(5):819.

19. Putra N, Kandou J, Leman MA. Gambaran kebersihan gigi dan mulut pada anak cacat di SLB YPAC Manado [Skripsi]. Manado: Universitas Sam Ratulangi; 2011.

20. Wowor VE. Hubungan antara status kebersihan mulut dengan status karies siswa Sekolah Menengah Atas Negeri 1 Manado [Skripsi]. Manado: Universitas Sam Ratulangi; 2013. 